\title{
Peculiarities of Using Plant Raw Materials in Breadmaking Technology
}

\author{
Zhanna Victorovna Novikova ${ }^{1 *}$, Sophie Mikhailovna Sergeeva1, Dmitry \\ Sergeevich Lavrinovich ${ }^{2}$,and Anton Alexeyevich Maksimkin ${ }^{1}$ \\ ${ }^{1}$ Moscow State University of Food Production, Moscow, Russia \\ ${ }^{2}$ National University of Science and Technology "MISIS", Moscow, Russia \\ ORCID \\ Zhanna Victorovna Novikova; 0000-0002-7358 \\ Dmitry Sergeevich Lavrinovich; 0000-0002-6606-6032
}

Corresponding Author: Zhanna Victorovna Novikova; email: novikova@mgupp.ru

\section{Dates}

Published 13 January 2022

Publishing services provided by Knowledge E

(c) authors. This article is distributed under the terms of the Creative Commons

Attribution License, which permits unrestricted use and redistribution provided that the original author and source are credited.

Selection and Peer-review under the responsibility of the 8th Scientific and Practical Conference Conference Committee.

\begin{abstract}
This research examined the scientific basis for an integrated approach to broadening bread and flour products. The effect of chia seeds on the organoleptic and physical-chemical indicators of the "sweet bun" (brioche) was studied to substantiate the use of plant raw materials in the technology of bread and flour product preparation.Chia seeds contain essential amino acids, vitamins (mainly B), minerals (calcium, potassium, iron, magnesium, phosphorus and zinc) and antioxidants, so it is possible to use chia seeds to obtain a product that combines high organoleptic properties and is also enriched with essential substances. The findings from the organoleptic evaluation of the test specimens indicated that the added ingredients significantly affected the appearance, crust color and crumb condition;however,there was no change in the taste and smell of the pastry. The effect of chia seeds on the quality of the products during storage was assessed. It was found that when using chia seeds in the amount of $10 \%$ of the mass of flour, after 24 hours the decline in taste, smell,crumb elasticity and friabilitywas less noticeable. In addition, the analysis of the chemical composition of the brioche bun showed thatthe products with chia seeds were highly nutritious. Thus, the content of dietary fiber in the model specimen wastwo times higher than the values of the control specimen (10\% of the daily requirement); the content of omega- 3 and omega- 6 polyunsaturated fatty acids was equivalent to $87.9 \%$ and $19.2 \%$ of the daily requirement, respectively. The use of chia seeds in a butter bun recipe (brioche) therefore enables theexpansion of the range of food products enriched with essential ingredients.
\end{abstract}

Keywords: bread and flour products, sweet bun, brioche, chia seeds

1. Introduction

The health of each individual and the nation as a whole is largely determined by the nutrition. Optimal nutrition is a key factor in high efficiency, life expectancy and preservation of the national gene pool. Nowadays, it is important to expand and improve the range of functional and specialized products in the food industry, along with the bakery industry. Satisfaction of demand of consumers for affordable high-quality products, including those produced from raw materials that are not traditional for our country has been becoming an urgent task. 
The issue of nutrition correction is relevant for the Russian Federation. Government policy in the framework of the implementation of the "Action Plan of the Federal Service for Supervision of Consumer Rights Protection and Human Wellbeing for the Period up to 2024" and "the Strategy for improving the quality of food products in the Russian Federation until 2030 " focused on providing nutritious food, preventing diseases, increasing the life expectancy and improving the quality of life of the population, stimulating the development of production and circulation of food products of appropriate quality on the market $[6,7]$.

Healthy diet is becoming a trend in modern society, which indicates the readiness of people to use healthy products in their diet. Companies in the catering industry are responding to consumer demands by expanding their range of familiar dishes. For example, there are a great number of varieties of burgers - from the classic, using traditional raw materials, to the original with the addition of various specific ingredients today. One of the main ingredients of the Burger is a bun, it takes around $40 \%$ of the mass of the ready-to-eat meals.

Considering the historically high share of the grain group in the consumer basket of the Russian population, researches in the development of recipe compositions and technologies for new types of bread and flour products in particular with the use of nontraditional plant raw materials, rich in useful substances necessary for the human body are becoming important. Famous scientists such as L. Ya. Auerman, T. G. Bogatyreva, A. A. Kochetkova, N. V. Labutina, L. I. Puchkova, R. D. Polandova, T. B. Tsyganova and others were developing and improving bread and flour products for a healthy $\operatorname{diet}[3,4]$.

An analysis of their work and their own researches has shown that one of the most promising raw materials is Chia seeds, which have a positive effect on the structural and mechanical properties of half-finished products and finished products[5].

Chia seeds contain biologically active substances and are used as a vegetable component in flour products. Chia seeds allow you to obtain a product that has not only high organoleptic properties, but also enriched with essential substances[1].

It is clear, that the development of recipes for baked goods using chia seeds is of great theoretical and practical interest and creates the conditions for expanding the range of special foods with high quality, nutritional and biological value.

The aim of this research was to demonstrate the use of vegetable raw materials in the manufacture of baked goods. 
TABLE 1: Brioche sample recipes

\begin{tabular}{|c|c|c|c|c|c|}
\hline \multirow[t]{2}{*}{ Raw materials } & \multicolumn{5}{|c|}{ Raw material consumption per $100 \mathrm{~kg}$ of flour, $\mathrm{kg}$} \\
\hline & Sample 1 & Sample 2 & Sample 3 & Sample 4 & Sample 5 \\
\hline $\begin{array}{l}\text { fancy white wheat } \\
\text { flour }\end{array}$ & 100 & 95 & 90 & 85 & 80 \\
\hline chia seeds & - & 5 & 10 & 15 & 20 \\
\hline butter & 24 & 24 & 24 & 24 & 24 \\
\hline hen's egg & 22 & 22 & 22 & 22 & 22 \\
\hline first sugar & 17 & 17 & 17 & 17 & 17 \\
\hline pressed yeast & 1,7 & 1,7 & 1,7 & 1,7 & 1,7 \\
\hline edible salt & 0,75 & 0,75 & 0,75 & 0,75 & 0,75 \\
\hline
\end{tabular}

\section{Materials and methods}

In the engineering center "Advanced Food Technologies and Food Safety" of the Moscow State University of Food Production the mathematical modeling of the bread recipe was carried out using the simplex method and the computer equipment. The optimization parameter was the content of macronutrients, fiber, omega- 3 and omega6 fatty acids. As a result of the mathematical modeling, 4 variants of the ratios of the variable components which correspond to the specified conditions were obtained (Table 1).

Note: Sample 1 - control sample of the sweet bun (brioche); Sample 2 - 5\% wheat flour replaced by chia seeds (TU 9761-005-11602363-2016); Sample 3 - 10\% wheat flour replaced by chia seeds; Sample 4 - 15\% wheat flour replaced by chia seeds; Sample 5 $-20 \%$ wheat flour replaced by chia seeds.

The dough was made using the technology of long-term cold fermentation for 8 hours at a temperature of $4 \pm 2^{\circ} \mathrm{C}$. The dough was then cut, shaped and left to rise for $60-90$ minutes at a temperature of $18 \pm 2{ }^{\circ} \mathrm{C}$. The products were baked in the baker's rack at a temperature of 190 to $200^{\circ} \mathrm{C}$ for 12 to 15 minutes.

To determine the effect of chia seeds on the storage of products during the guaranteed shelf life, the study samples were placed for storage. Freshness was assessed $3,8,16,24$ hours after baking. The quality of the control and study samples was assessed according to the regulated quality indicators (GOST 24557-89): mass fraction of moisture, porosity and acidity. The degree of the crumb staleness was determined according to the method of $5 \mathrm{C}$ on the device (indenter "cylinder 36"), a piece of crumb with a weight of $5 \pm 0.2 \mathrm{~g}$ was taken for the examination.

The swelling of the crumb ( $\mathrm{ml} 1 \mathrm{~g}$ dry matter) was determined by the amount of water which was absorbed by the crumb after 5 minutes. 
Crum friability was determined by the particles of crumbs formed as a percentage when the crumb sample was shaken (15 minutes at a speed of 190 to $250 \mathrm{rpm}$ ).

The analysis of the food and energy value of products was carried out using the calculation method [8].

\section{Results and discussions}

The development of recipes for new bread and flour products is based on the regularity of the quality indicators for finished products, depending on the quantity of the unconventional raw material added. The organoleptic estimation of the studysamples enables us to draw conclusions about the influence of the ingredients introduced on the appearance, the color of the crust and the condition of the crumb of the product. However, the additives have no visible influence on changes in the taste and smell of baked products. As a result of the tasting analysis, the highest total score for Sample No. 3 was obtained, which was characterized by a required shape, a light brown crust color interspersed with chia seeds, as well as a crumb clarity, a sweet taste and a characteristic aroma for a rolls and buns.

The effect of chia seeds on the quality of the products during storage was monitored by changes in the organoleptic and physicochemical parameters (mass fraction of moisture, swelling, crumb friability, acidity and porosity). The results are shown in Figure 1.

After 8 hours of storage, no significant changes in the organoleptic properties were found in all study samples. After 16 hours, the samples showed a decrease in crumb elasticity and an increase in crumb friability, to a lesser extent the changes in sample 3 were expressed. After 24 hours of storage, all samples became stiffer and the crumb less elastic. When using chia seeds in an amount of $10 \%$ by weight of the flour in the product, however, a decrease in the characteristics such as taste, smell, crumb elasticity and friability were less noticeable. Even though all study samples are of better quality compared to the control sample in terms of organoleptic and physicochemical indicators, sample 3 shows higher indicators during the storage, affects the product's consumer properties. The chemical composition of the control and study sample 3 (Table 2) were analyzed $[2,8,9]$.

It is known that chia seeds are characterized by a high content of proteins, polyunsaturated fatty acids and dietary fiber, which determines the high nutritional value of products produced when they are used. Dietary fiber is classified as an essential micronutrient that fulfills important physiological functions in the human body. The fiber 

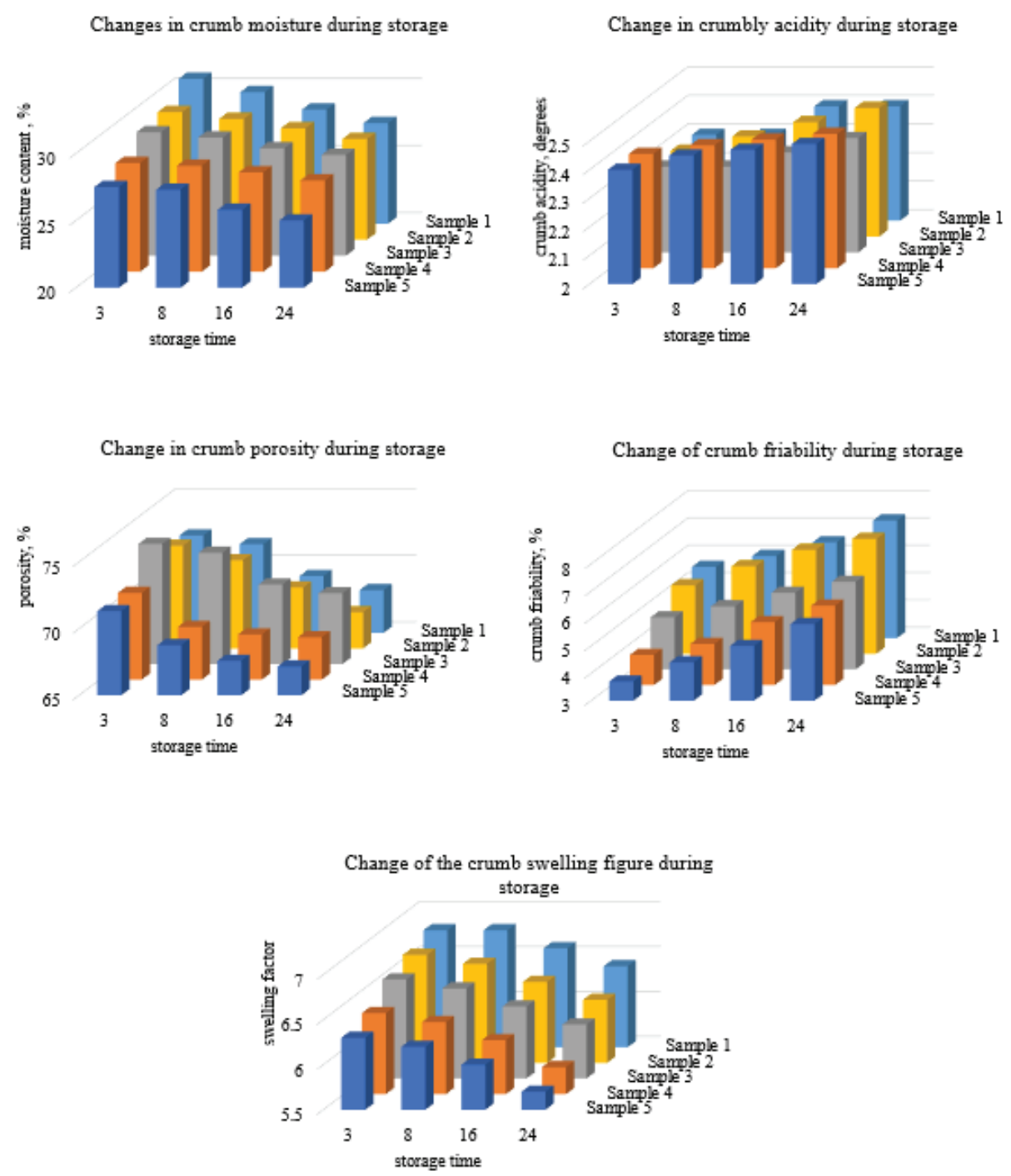

Figure 1: The influence of the addition of chia seeds on the physico-chemical parameters in the storage of buns (brioches).

content in the study sample is twice that of the control sample and covers $10 \%$ of the daily requirement. Thus, the high content of polyunsaturated omega- 3 and omega- 6 fatty acids in chia seeds, which are required to support cognitive abilities, heart and vascular function, the daily needs by $87.9 \%$ and $19.2 \%$ cover.

\section{Conclusions}

Based on the studies conducted, it was found that the use of chia seeds in the recipe for brioche (brioche) allows to expand the range of fortified grains that cater to the needs and satisfy expectations of consumers. 
TABLE 2: Comparative properties of the basic nutrient content and the energy value of finished products (per 65 grams)

\begin{tabular}{|c|c|c|c|c|}
\hline \multirow[t]{2}{*}{ Nutrient materials } & \multicolumn{2}{|c|}{ Study sample 1} & \multicolumn{2}{|c|}{ Study sample 3} \\
\hline & $\begin{array}{l}\text { contents in } 1 \\
\text { serving }\end{array}$ & $\begin{array}{l}\text { daily } \\
\text { requirement, } \\
\%\end{array}$ & $\begin{array}{l}\text { contents in } 1 \\
\text { serving }\end{array}$ & $\begin{array}{l}\text { daily } \\
\text { requirement, } \\
\%\end{array}$ \\
\hline Proteins, $\mathrm{g}$. & 5,8 & 7,7 & 6,1 & 8,1 \\
\hline Fats, $g$ & 7,8 & 9,4 & 9,1 & 11 \\
\hline Carbohydrates, g. & 35,1 & 9,6 & 34,1 & 9,3 \\
\hline Dietary fibers, g. & 1,5 & 5,0 & 3,0 & 10,0 \\
\hline $\begin{array}{l}\text { Omega-3 polyunsatu- } \\
\text { rated fatty acid, g. }\end{array}$ & 0,04 & 3,8 & 0,9 & 87,9 \\
\hline $\begin{array}{l}\text { Omega- } 6 \text { polyunsatu- } \\
\text { rated fatty acid, g. }\end{array}$ & 0,5 & 12,9 & 0,8 & 19,2 \\
\hline Nutrition value, kcal & 230,9 & 9,2 & 236,8 & 9,5 \\
\hline
\end{tabular}

\section{References}

[1] Bechthold A. Chiasamen - Präkolumbisches Grundlebensmittel und modernes Novel Food. Ernährungsumschau. 2015;3:9-12.

[2] Vilsack T. Chia seeds. USDA.GOV. 4/1/2019 Available from: https://fdc.nal.usda.gov/fdc-app.html\#/food-details/784468/nutrients.

[3] Gubenko GY, Mayurnikova LA, Rubchevskaya LP. Prospects for the integrated use of regional non-traditional vegetable raw materials in the production of food products. Food Industry. 2016;4:23-27.

[4] Zaitseva LV, Yudina TA, Ruban NV, Bessonov VV, Mehtiev VS Modern approaches to the development of recipes for gluten-free bakery products. Nutritional Issues.2020;1:77-85.

[5] Novikova ZV, Zakharova AD, Maksimkin AA,Semisazhonova YA. Prospects for the use of non-traditional raw materials in the Russian food industry. Technology and Commodity Science of Innovative Food Products. 2018;6(53);55-62.

[6] Order of the Government of the Russian Federation of June 29, 2016 N1364$r$ "On approval of the Strategy for improving the quality of food products in the Russian Federation until 2030".ConsultantPlus. 2016 June 29. Available from: http://www.consultant.ru/document/cons_doc_LAW_200636/.

[7] The plan of activities of the Federal Service for Supervision of Consumer Rights Protection and Human Welfare for the period up to 2024.ConsultantPlus. 2019/02/01 Available from: http://www.consultant.ru/document/cons_doc_LAW_332104/.

[8] TR CU 022/2011. Technical regulations of the Customs Union. Food products in terms of their labeling. ConsultantPlus. 2011/12/9 Available from: 
http://www.consultant.ru/document/cons_doc_LAW_124614/.

[9] Tutelyan VA. Chemical composition and caloric content of Russian food products. Moscow: DeLi plus; 2012. 